\title{
Research on Innovation of Mental Health Education in Independent Colleges
}

\author{
Fang Wang, Hui Zhang \\ Jincheng College of Nanjing University of Aeronautics and Astronautics, Nanjing, Jiangsu, 211156
}

Keywords: Independent Colleges, Mental Health Education, Creative Research

\begin{abstract}
Today's society is in the period of change, the spear and confusion of college students in learning, living and social adaptation and other aspects are increasing, a variety of psychological problems and psychological barriers are increasing frequently. Therefore, it is one of the important subjects that higher education and theoretical workers urgently need to solve the problem of strengthening the research of mental health education of college students.
\end{abstract}

\section{Introduction}

Independent college is a new institution in the process of popularization in accordance with the new mechanism "new model of full-time university! Independent college in the school model" personnel training "source of funds" quality of students and other institutions compared with ordinary institutions, with its certain specialities and limitations! Independent college students have become a special group in our college students, showing different psychological characteristics and psychological problems with ordinary college students, which determine the independent college students mental health education work complex Therefore, based on the social and independent college students group psychology changes, conform to the development trend of college students mental health education, to build an effective "different from the general institutions of higher education mental health education model is to improve On the Effect of Psychological Health Education in Independent Colleges.

In recent years, the study of mental health problems of college students shows that a considerable number of college students have psychological reactions and adaptive barriers, especially in independent college students there are self-awareness, self-evaluation and other psychological conflicts and psychological barriers. Independent college students because of social evaluation, self evaluation and other factors, the study and life in an independent college had a sense of inferiority, that the independent college to learn to become three college students, in the self-consciousness there is depression, self-experience Negative, self-emotional out of control and self-realization of self-esteem and other weaknesses. Did not see their own should be the positioning of their own future development is at a loss. Independent college students are always sensitive to interpersonal relationships. Some of the students who are studying here have better family conditions, some are more difficult, have different quests and goals for learning and life, so they have become sensitive and jealous of interpersonal relationships, interpersonal relationships between dorms, men and women The interaction between students is particularly prominent, like to self-centered for interpersonal relationships. In the independent college, most students lack a clear learning goal, lack of active learning consciousness, passive acceptance of teachers' teaching requirements and assessment, in the learning target positioning is not accurate, learning attitude is not correct, the vast majority of students only to mix Zhang diploma, some students learn to be at a loss, often showing melancholy mood. In their own sexual health and sexual intercourse with the process of sexual problems are more confused, which seriously affected the psychological impact of the students' learning and physical and mental health. Because of the educational system and management system of the independent college, the mental health knowledge is difficult to be fully popularized. The students get a little knowledge of this knowledge, and know little about the mental health knowledge or the poor mental health consciousness. In this case, the formation of a mental 
health, psychological counseling narrow understanding of psychological problems equivalent to mental illness, taboo jealousy, in the early stages of the formation of many psychological problems did not get a good guide, let its development, resulting in a serious Psychological disorder.

\section{The Current Situation of Mental Health Education in Schools}

Most of the independent colleges have established a team of teachers of mental health education with full-time teachers, counselors and class teachers as the main body. However, most teachers have not received formal and systematic training of psychological knowledge and skills. A considerable number of teachers have applied to modern psychological counseling Know less, in the practice of education and counseling is difficult to ensure good results, can not meet the needs of students. Through the classroom teaching to the students to teach mental health knowledge and psychological adjustment methods to help students improve their ability to adapt to social life, develop good personality quality, is the independent college to carry out the main way of college students mental health education. In fact, many independent colleges do not set up mental health education courses, some schools only as elective courses, but are not included in the teaching plan; some of the mental health education into the ideological and moral class, only as one of the chapters , Far from meeting the needs of students.

Some teachers believe that mental health education is the work of psychological teachers, and they have nothing to do, so that the school mental health education can only rely on psychological teachers to carry out a thinly. There are problems let the students find mental health teachers, in the school did not form a large number of teachers are concerned about the mental health of students education environment.

\section{The Main Factors that Affect the Mental Health of Students in Independent Colleges}

For most independent college students, psychological trauma or from the college entrance examination of the failure, although they have the opportunity to enter the university gate to accept higher education, but objectively speaking, most of them are college entrance examination students. As China's current education system, college entrance examination failure to give young students to combat is still underestimated. For this part of the poor academic performance and access to independent college students, it is easy to produce strong inferiority and anxiety. The lack of self management consciousness and ability is one of the factors of psychological conflict of independent college students. For independent college students, from the beginning of their entry into the school, around the three brought social evaluation to follow their college life, on the one hand, into the university life they want to have a new life, the other On the one hand, around the three brought social evaluation and let them experience the complex inner feelings, or guilt or shame. Independent colleges of high fees, low employment for many students caused some pressure, which let part of an independent college students living, learning to increase the pressure, and even worse for the development of neurological anxiety disorder.

\section{Analysis of the Causes of the Problems in Mental Health Education in Independent Colleges}

Throughout the past few years, China's mental health education work situation is not difficult to find, whether managers or educators of mental health education are not enough in place. From the social point of view, due to the historical and cultural traditions, people's attention to the psychological quality of personality "awareness" research is not enough. From the standpoint of independence college has some managers and teachers have misunderstandings about mental health education. At present, the vast majority of independent colleges have implemented mental health education, but there are large gaps in the corresponding security conditions, such as lack of funds or not in place; lack of teachers; system is not perfect, institutional disorder and other issues, leading to mental health education Difficult to follow the educational goals. Although a small number of independent colleges have explored a better educational method, most of the independent college's 
mental health education work is still the dark in the ship, mainly with the enthusiasm of the workers and experience to promote the work, inevitably into the misunderstanding. Due to the lack of scientific guidance and comprehensive development planning, the work of many independent colleges is still on the surface, the work of subjectivity and arbitrariness is very strong. In practice, part of the independent college theory research and practice is not close to the phenomenon of serious. Judging from the number of articles published in recent years, the achievements of mental health education work is considerable, but from the actual implementation of mental health education, the effect is not satisfactory.

\section{A Probe into the Methods of Psychological Health Education for Independent College Students}

The establishment of all students is the object of the development of mental health education model. To achieve the school students as the goal of the development of mental health education, first of all, a necessary way is to let the psychology into the classroom. In the Opinions issued by the Ministry of Education in 2001 on strengthening the mental health education of college students in colleges and universities 6 , it has been pointed out that mental health education should take classroom teaching and extracurricular guidance as the main channel and basic link. Second, the school is to carry out various forms of psychological and mental health knowledge campaign. To the school students as the object of education, different topics, different times held a variety of mental health lectures, while the use of various media widely public health knowledge.

In view of the main psychological problems of contemporary college students, we should carry out self-consciousness and mental health in college students, improve personality and mental health, interpersonal and mental health, study, career and mental health, sex, love and mental health, network and mental health, Psychological counseling and psychological treatment and other aspects of education. Such as the new students to the occasion of the new students to adapt to the main content of the first grade to college students self-awareness, interpersonal relationships as the content of the second grade to college students love and marriage psychology, life and life, career design for the third grade to employment The main content, so that students systematically understand their own psychological development and changes in the law to create a sound personality, improve the level of mental health. The construction of full-time teachers as the backbone, special combination, professional complementarity, relatively stable, high quality independent college students mental health education work team has become an urgent task at this stage, but also do a good job of mental health education key. School counseling centers should take various forms of regular targeted training to them, so that they master the way of mental health education in the process of daily thinking to help students solve some psychological problems, improve the level of mental health education. Mental health education is a systematic project, school education should be the main force with the family, the community together, to obtain their support and help. Such as parents divorced, improper family education, social bad atmosphere and other factors, will have a great impact on the psychological students can easily lead to psychological problems. As the main environment for college students to study and live, the school should take the initiative to pay attention to the growth of students, and actively create conditions to communicate with parents in a timely manner, a comprehensive feedback on student status, to discuss student growth plans, especially for psychological problems students should pay attention , Timely and effective intervention with the family to take measures, which is to reduce adverse events, scientific education effective way.

\section{Conclusion}

Independent college is an important part of higher education in our country. Independent college students' mental health education is a highly complex basic engineering, systems engineering and innovation project. We should scientifically analyze the status quo and problems of students' mental health education, and actively guide students to participate in mental health education activities. 
Only in this way, students can receive a good educational effect of mental health education.

\section{Acknowledgment}

In-school research start-up fund: Studies on the Identification, Pathogenesis and Drug Sensitivity of Phyllostachys praecox Blight Disease.

Project No. 20160426

\section{References}

[1] Liang Yingchun, Zhao Aijie. Independent college students psychological analysis [J]. Contemporary Education Forum, 2008 (03)

[2] Shen Zhuanghai, Li Yan. Focus on humanistic care and psychological counseling: innovative ideological and political work of the new requirements [J]. Ideological and political work, 2008 (02)

[3] Weng Tao. Contemporary college students psychological problems and its causes [J] .Hubei University of Economics, 2008 (01)

[4] Liu Yanhua. Analysis of college students' psychological problems and solutions [J]. Heilongjiang Science and Technology Information, 2008 (02)

[5] Li Liang. Independent college students employment psychology analysis [J]. Technology economy market, 2008 (01)

[6] Ma Dexiu. Pay attention to humanistic care and psychological counseling to enhance the effectiveness of ideological and political work in colleges and universities [J]. China Higher Education, 2007 (21) 